\title{
About Application the Tyre-Road Adhesion Determination of a Vehicle Equipped with an Automated System of Brake Proportioning
}

\author{
D. N. Leontiev ${ }^{1)}$, I. N. Nikitchenko' ${ }^{1)}$,. A. Ryzhyh ${ }^{1)}$, S. I. Lomaka ${ }^{1)}$, O. I. Voronkov'), I. V. Hritsuk ${ }^{2)}$, \\ S. V. Pylshchyk ${ }^{3)}$, O. V. Kuripka ${ }^{1)}$ \\ ${ }^{1)}$ Kharkov National Automobile and Highway University (Kharkiv, Ukraine), \\ ${ }^{2)}$ Kherson State Maritime Academy (Kherson, Ukraine), \\ ${ }^{3)}$ Kherson State University (Kherson, Ukraine) \\ (C) Белорусский национальный технический университет, 2019 \\ Belarusian National Technical University, 2019
}

\begin{abstract}
The paper considers a method for calculation and evaluation of an automated brake proportioning system and it also describes assessment of efficiency while using cohesion forces of an automated system during vehicle braking process (MAZ 256200 taken as an example). A method for efficiency estimation of the vehicle braking equipped with an automated brake proportioning system is graphically presented in the paper. A comparable analysis has been made in order to evaluate vehicle braking efficiency in three various conditions of its wheel motion during braking process. The paper contains description of braking processes for a vehicle at its idealized braking, at braking with an operating automated system and at braking with blocked wheels. Mathematical dependences have been proposed and they make it possible to calculate a coefficient of cohesion forces used by an automated brake proportioning system on the basis of time parameters for vehicle braking process. The proposed mathematical dependences take into account design peculiarities of the automated system, i.e. a diagram of modulator arrangement on axes of the vehicle. The executed analysis for calculation accuracy of the coefficient pertaining to use of cohesion forces of the automated system with and without taking into accout rolling force resistance of the vehicle wheels has demonstrated a possibility to apply the proposed calculation methods for carrying out auto-technical expertise while investigating road-traffic accidents involving transport facilities equipped with such systems as ABS. The paper proposes a dependence for identification of a vehicle braking distance on the basis of the coefficient on use of cohesion forces by the automated brake proportioning system. The executed experimental investigations on both test and serial models of the automated brake proportioning system have allowed to justify theoretical discussions concerning application of tyre-road adhesion in the operational process of the vehicle brake proportioning system. The investigation results have shown high efficiency of the test automated brake proportioning system developed by Chair of Automobiles in the name of A. B. Hredescul at Kharkiv National Automobile and Road University under the following braking conditions: dry road surface and compacted snow cover.
\end{abstract}

Keywords: automated brake proportioning systems, ABS, braking system, brake control, realised adhesion, synergy of wheel and bearing surface, coefficient of used cohesion forces, braking distance, stopping distance, vehicle

For citation: Leontiev D. N., Nikitchenko I. N., Ryzhyh L. A., Lomaka S. I., Voronkov O. I., Hritsuk I. V., Pylshchyk S. V., Kuripka O. V. (2019) About Application the Tyre-Road Adhesion Determination of a Vehicle Equipped with an Automated System of Brake Proportioning. Science and Technique. 18 (5), 401-408. https://doi.org/10.21122/2227-1031-2019-18-5-401-408

\section{Об использовании сил сцепления колес транспортного средства, оборудованного автоматизированной системой регулирования тормозного усилия}

\author{
Кандидаты техн. наук, доценты Д. Н. Леонтьев ${ }^{1)}$, И. Н. Никитченко ${ }^{1)}$, \\ кандидаты техн. наук, профессора Л. А. Рыжих ${ }^{1)}$, С. И. Ломака', \\ доктора техн. наук, доценты А. И. Воронков ${ }^{1)}$, И. В. Грицук ${ }^{2)}$, \\ преподаватель С. В. Пильщик ${ }^{3)}$ магистр А. В. Курипка ${ }^{1)}$ \\ ${ }^{1)}$ Харьковский национальный автомобильно-дорожный университет (Харьков, Украина), \\ ${ }^{2)}$ Херсонская государственная морская академия (Херсон, Украина), \\ ${ }^{3)}$ Херсонский государственный университет (Херсон, Украина)
}

Реферат. В статье рассмотрен метод расчета и оценки автоматизированной системы регулирования тормозного усилия, а также выполнена оценка эффективности использования силы сцепления автоматизированной системой в процессе

\begin{tabular}{ll}
\hline Адрес для переписки & Address for correspondence \\
Леонтьев Дмитрий Николаевич & Leontiev Dmitriy N. \\
Харьковский национальный автомобильно-дорожный университет & Kharkov National Automobile and Highway University \\
ул. Ярослава Мудрого, 25, & 25 Yaroslava Mudrogo str., \\
61002, г. Харьков, Украина & 61002, Kharkiv, Ukraine \\
Тел.: +38057 707-37-69 & Tel.:+38057 707-37-69 \\
dima.a3alij@gmail.com & dima.a3alij@gmail.com
\end{tabular}


торможения колесного транспортного средства (на примере автобуса МАЗ 256200). Графически представлен и обоснован способ оценки эффективности торможения транспортного средства, оборудованного автоматизированной системой регулирования тормозного усилия. Проведен сравнительный анализ эффективности торможения транспортного средства в трех разных условиях движения его колес при торможении. Описаны процессы торможения при идеализированном торможении, торможении при работе автоматизированной системы, а также при торможении транспортного средства с заблокированными колесами. Предложены математические зависимости, позволяющие рассчитать коэффициент использования силы сцепления автоматизированной системой регулирования тормозного усилия на основе временных параметров процесса торможения транспортного средства. Предложенные математические зависимости учитывают особенности конструкции автоматизированной системы, т. е. схему расположения модуляторов на осях колесного транспортного средства. Выполненный анализ точности расчетов коэффициента использования силы сцепления автоматизированной системой с учетом и без учета сил сопротивления качения колес транспортного средства показал возможность использования предложенных методов расчета в практике автотехнических экспертиз при расследовании дорожно-транспортных происшествий с участием транспортных средств, оборудованных такими системами, как ABS. Предложена зависимость определения тормозного пути колесного транспортного средства на основе коэффициента использования силы сцепления автоматизированной системой регулирования тормозного усилия. Выполненные экспериментальные исследования опытного и серийного образцов автоматизированной системы позволили подтвердить теоретические рассуждения в отношении использования сил сцепления в процессе работы автоматизированной системы регулирования тормозного усилия колесного транспортного средства. Результаты исследований показали высокую эффективность работы экспериментальной автоматизированной системы, разработанной на кафедре автомобилей имени А. Б. Гредескула Харьковского национального автомобильнодорожного университета, в условиях торможения транспортного средства на сухом асфальтовом и укатанном снежном покрытиях.

Ключевые слова: автоматизированные системы регулирования тормозного усилия, ABS, тормозная система, тормозное управление, реализуемое сцепление, взаимодействие колеса с опорной поверхностью, коэффициент использования силы сцепления, тормозной путь, остановочный путь, транспортное средство

Для цитирования: Об использовании сил сцепления колес транспортного средства, оборудованного автоматизированной системой регулирования тормозного усилия / Д. Н. Леонтьев [и др.] // Наука и техника. 2019. Т. 18, № 5. C. 401-408. https://doi.org/10.21122/2227-1031-2019-18-5-401-408

\section{Introduction}

The modern society actively utilises vehicles in everyday life, and this fact influences the traffic safety. To enhance the latter automated systems of brake proportioning were installed since the middle of the $20^{\text {th }}$ century. Although electronic devices appeared, the rate of road accidents remains on the high level. In this regard there appear issues connected with the definition of objective parameters of a vehicle motion.

\section{Sources analysis}

As far as we know from forensic science, the good condition of the brake control contributes greatly to the safe driving a vehicle. According to UN/ECE R13-09: 2002 brake control of a modern vehicle is equipped with at least three braking systems such as the service, the emergency and the parking one.

Increase of the efficiency of the mentioned braking systems is provided by automated (ABS, ESB, EBL, EBD) or automatic (source stability) systems. But in spite of the automated devices installed on the braking systems, we still need some time to brake the vehicle. The braking distance depends on the initial braking speed, reaction of a driver and the speed at which braking finishes (fig. 1).

If the trace of the tyre protector remained on the road, the braking distance can be quite accurately calculated by means of the following relation (1) [1].

$$
S_{\text {stoped }}^{b l} \approx \frac{v_{b}-v_{e}}{3,6}\left(t_{r}+t_{p}+\frac{t_{s}}{2}\right)+S_{a d h}^{b l},
$$

where $v_{b}, v_{e}$-speed at the beginning and the end of the braking process, km/hour; $t_{r}$ - time of reaction of a driver, $\mathrm{s} ; t_{p}$ - time of pressure increase in the drive of the braking system of a vehicle, $\mathrm{s} ; t_{s}$ - time of the vehicle slowdown increase, s; $S_{a d h}^{b l}$ - length of the tyre protector trace, $\mathrm{m}$

$$
S_{a d h}^{b l} \approx \frac{\left(v_{b}-v_{e}\right)^{2}}{25.92 g f_{b l}} ;
$$

$g=9.81 \mathrm{~m} / \mathrm{s}^{2}-$ acceleration of freefall; $f_{b l}-$ coefficient of adhesion that is calculated while dragging the blocked wheel on the road surface. 
Applying relation (1) it is not difficult to identify the initial speed of the vehicle braking before an accident takes place. It should be noted that the result of calculation by means of relation (1) is based on the so-called blocked wheel adhesion coefficient, that is calculated through the special methodology [1], the essence of which is presented mathematically by the following relation:

$$
f_{b l}=\frac{P_{b}}{G_{a}},
$$

where $P_{b}$ - force of pulling the blocked wheel, N; $G_{a}$ - weight with which the wheel presses on the road surface, $\mathrm{N}$.

Owing to the fact, that most vehicles are equipped with automated or automatic systems preventing wheels blockage, application of relation (1) which includes relation (2) does not allow objective evaluating an accident outbreak. That is because automatic systems may apply properties of tyre-road adhesion in different ways, depending on the mode of a vehicle movement. [1-10].

\section{Objective and problem statement}

The objective of the following research work is to define the braking distance of a vehicle equipped with an automated system of brake proportioning. The task of this work is to develop a methodology for calculation the stopping distance of a vehicle using the coefficient of application the tyre-road adhesion phenomenon by an automated or automatic system of brake proportioning.

\section{Theoretical basis of methodology for calculating the braking and the stopping distance of a vehicle}

It is known that when wheels are rolling, the tyre adhesion coefficient does not coincide with the coefficient of a blocked wheel $[1,5]$. Therefore, application of relation (2) for calculating the stopping distance by means of relation (1) is impossible. So instead of relation (2) we use relation (4) to calculate the stopping distance in case the wheels of a vehicle are rotating. This relation (4) respects the influence of the automated brake proportioning system on the process of braking a vehicle

$$
S_{a d h}^{\text {with } A B S} \approx \frac{\left(v_{b}-v_{e}\right)^{2}}{25.92 \varepsilon j_{m}},
$$

where $\varepsilon$ - dimensionless coefficient of application of the tyre-road adhesion by an automated brake proportioning system; $j_{m}$ - average deceleration of the vehicle, $\mathrm{m} / \mathrm{s}^{2}$.

Coefficient of application the tyreroad adhesion is calculated experimentally for every series of vehicles equipped with automated systems. Experiments are carried out on certified testing grounds. According to European standards [6] vehicle equipped with $\mathrm{ABS}$ are allowed to be exploited provided that the coefficient of wheel traction application while operating this system does not exceed the range of 0.75 , in any climate and weather related conditions. The upper range may be increased by $10 \%$ that is connected with accuracy of calculating of the coefficient of application of the wheel traction.

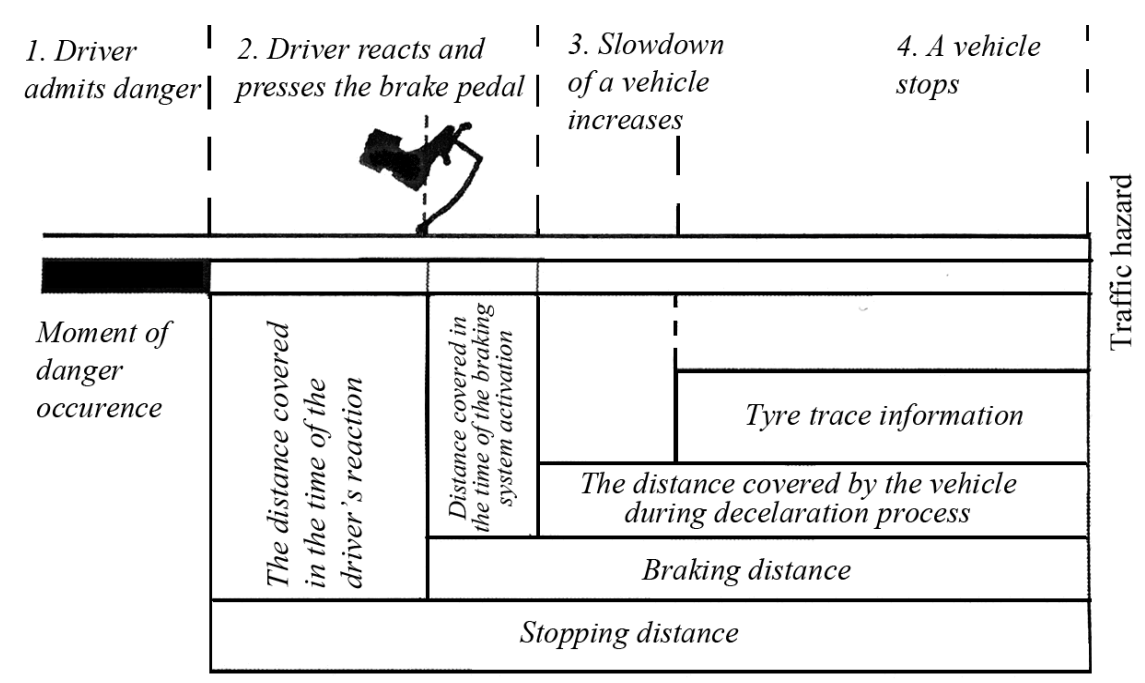

Fig. 1. Illustration of stages of breaking a vehicle 
Certifying a modern vehicle on the basis of application the tyre-road adhesion and conditions of compliance with the requirements of the vehicle resistance, there are defined the following categories of ABS: I category, II category or III category [6].

To understand the physical nature of the coefficient of application the tyre-road adhesion by an automated system, we must investigate various processes of braking the vehicle with the same initial speed (fig. 2).

In the (fig. 2) there are presented processes of braking a vehicle in 3 different modes: braking with blocked wheels, idealised braking and braking of a vehicle under the influence of ABS.

In the (fig. 2) there are the following symbols: $v_{a}^{b l}$ and $v_{w}^{b l}$ denote the speed of a vehicle and one of the wheels in the mode of braking with blocked wheels; $v_{a}^{i d}$ and $v_{w}^{i d}$ denote the speed of a vehicle and one of the wheels in case of idealised braking; $v_{a}^{\text {with } A B S}$ and $v_{w}^{\text {with } A B S}$ - mean speed of the vehicle and one of the wheels when braking is done by the ABS.

Analysing processes of braking presented in (fig. 2) we can make several conclusions: firstly, using automated brake systems deteriorates the quality of braking in comparison to the idealised process of braking, secondary the automated systems improves properties of braking compared to braking with blocked wheels. However comparing the mentioned processes is not quite proper, since there are different grip processes between the vehicle and the road surface. Thirdly the maximum value of slowing down the vehicle that is forced to brake by means of the automated brake proportioning systems is a bit lower than slowing down the vehicle by means of grip properties between the tyre and the road surface. The third conclusion lies in the fact that that, the automated systems grip brake proportioning spends some time for brake release of the wheels and, thus deteriorates the effectiveness of braking compared to idealised braking.

Is is obvious from the graphic of deceleration (fig. $2 \mathrm{~b}$ ) that relation $j_{\text {with }} A B S$ to $j_{i d}$ is the coefficient of application the tyre adhesion $(\varepsilon)$. It can be presented mathematically in the following way:

$$
\varepsilon=\frac{j_{w i t h A B S}}{j_{i d}} .
$$

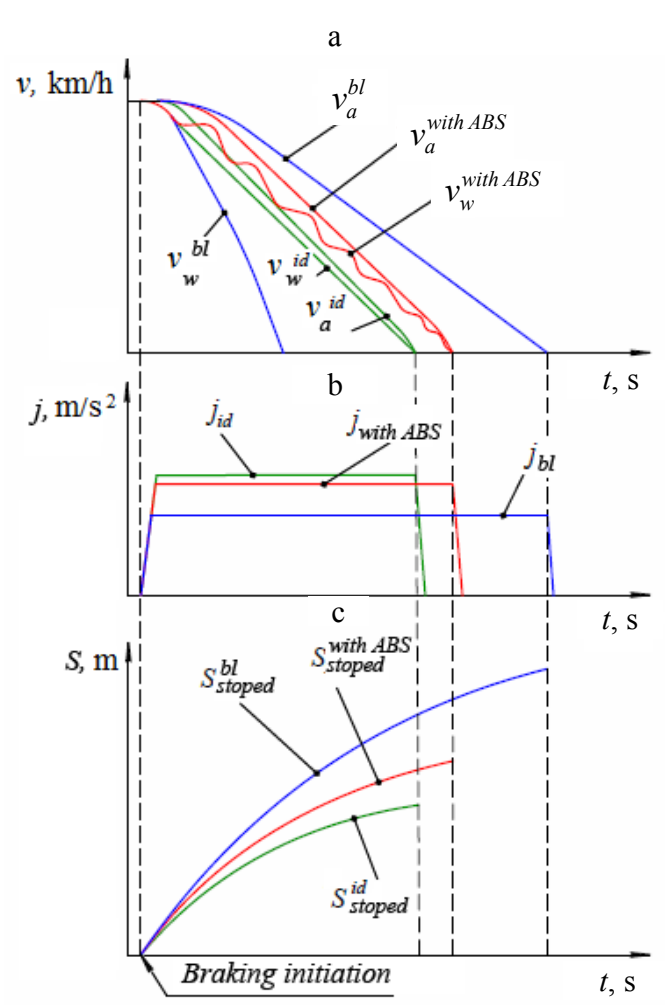

Fig. 2. Graphical presentation of various processes of breaking a vehicle

If to assume theoretically that slowing down of the vehicle with the working automated brake proportioning system started at the same speed as slowing down under idealised conditions, we can record the following:

$$
\varepsilon=\frac{t_{i d}}{t_{\text {with } A B S}},
$$

where $t_{i d}$ - time interval of braking the vehicle under the speed reduction $40 \mathrm{~km} /$ hour to $20 \mathrm{~km} /$ hour at the edge of the adhesion property of all the wheels of a vehicle and the road surface. This is done without application the automated brake proportioning system; $t_{\text {with } A B S}$ - time interval of braking the vehicle under the speed reduction $40 \mathrm{~km} /$ hour to $20 \mathrm{~km} /$ hour with operating the brake proportioning system.

However it is necessary to mention that reconstruction of the braking process conditions (especially the ideal ones) is a difficult task, that can be influenced by a number of facts. Therefore international standards [6] suggest calculating the coefficient of application the tyre-road adhesion by means of relation (7) taking into account the influ- 
ence of the resistance value of the front and back wheels and operational features of the brake proportional system as well

$$
\varepsilon=\frac{j_{S}}{g k_{M}},
$$

where $j_{S}$ - average slowing down of the vehicle that had been made to brake by means of the automated brake proportioning system; $k_{M}$ - means the average value of the maximally realised wheel traction of the vehicle when the latter is made to brake in the proper operational conditions $(k$-factor of the power-driven vehicle $[6,11-15])$

$$
k_{M}=\frac{f_{1} F_{1}^{d y n}+f_{2} F_{2}^{d y n}}{G_{a}} ;
$$

$f_{1}, f_{2}$ - maximally realised adhesion between wheels and the road surface on the corresponding axes of the vehicle [6]:

$$
\begin{gathered}
f_{1}=\frac{z_{i d(1)} L-0.015 a}{b+h z_{i d(1)}} \\
f_{2}=\frac{z_{i d(2)} L-0.010 b}{a-h z_{i d(2)}}
\end{gathered}
$$

$F_{1}^{d y n}, F_{2}^{d y n}$ - dynamical loads on the corresponding axes of the vehicle which is made to brake under the influence of the brake proportioning system:

$$
\begin{aligned}
& F_{1}^{d y n}=\frac{G_{a}}{L}\left(b+h z_{S}\right) ; \\
& F_{2}^{d y n}=\frac{G_{a}}{L}\left(a-h z_{S}\right) .
\end{aligned}
$$

In relations (9)-(12) we use such parameter as the coefficient of braking $(z)$, that allows evaluating the intensity of stopping a vehicle ideal braking and when applying the brake proportioning systems as well.

It should be noticed that when calculating the maximum realised adhesion, the coefficient of braking should be applied $\left(z_{i d(i)}\right)$ which is obtained when the wheels are rolling on the edge of adhesive properties between tyres and the road surface [6]. Also, when calculating dynamic loads on an axis of a vehicle, the coefficient of braking $\left(z_{S}\right)$ should be applied [6].

Coefficient of braking in idealised conditions and braking with the automated system can be calculated by means of the corresponding relations [6]:

$$
\begin{gathered}
z_{i d(i)}=\frac{0.566}{t_{i d(i)}} ; \\
z_{S}=\frac{0.849}{t_{S}},
\end{gathered}
$$

where $t_{i d(i)}$ - time interval of braking the vehicle under deceleration of $40 \mathrm{~km} /$ hour to $20 \mathrm{~km} /$ hour on the edge of grip features between the wheels of the axes and the road surface without application the automated systems of brake proportioning; $t_{S}-$ time interval of braking the vehicle under deceleration of $45 \mathrm{~km} /$ hour to $15 \mathrm{~km} /$ hour with application the brake proportioning system.

In the (fig. 3) there is displayed the difference between the time of braking the vehicle with the brake proportioning system and the time of braking the vehicle in case of idealised braking.

It is known from technical and scientific sources [1-6] that a brake proportioning system can be installed only on certain axes of a vehicle. That is why we should admit that relation (7) at this rate turns into relations (15) and (16).

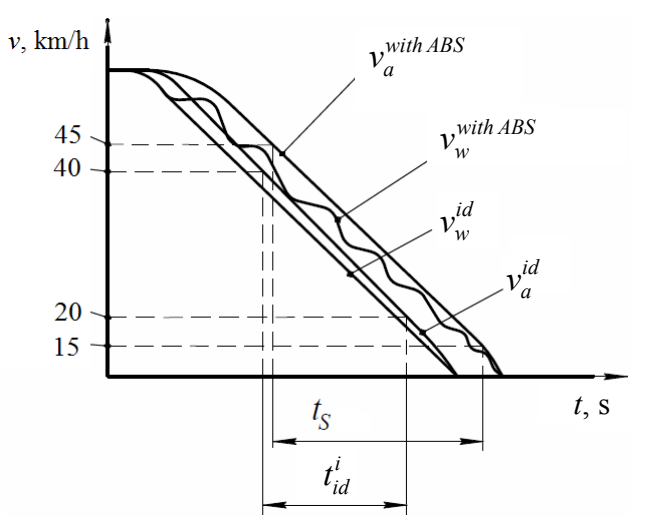

Fig. 3. Comparison of idealised braking and braking with application a brake proportioning system

When calculating the coefficient of application of traction by the automated brake proportioning system that is installed on the front axes of a vehicle, we should consider influence of the back wheels rolling resistance on the front axes as well 
as dynamic load applied and maximum realised adhesion. So, in this case the coefficient of application the tyre-road adhesion can be calculated by means of relation $[1,6]$

$$
\varepsilon_{\text {front }}=\frac{z_{S} G_{a}-0.015 G_{2}}{f_{1} F_{1}^{d y n}} .
$$

In case the automated system is installed only on the rear axis, the coefficient of application the tyre-road adhesion is defined by means of relation $[1,6]$

$$
\varepsilon_{\text {rear }}=\frac{z_{S} G_{a}-0.01 G_{1}}{f_{2} F_{2}^{d y n}},
$$

where $G_{1}, G_{2}$ - normal reactions of the road surface under static conditions, on certain axes of a vehicle.

If relations (7), (15) and (16) are expressed by means of relations (13) and (14), and also considering that $j_{S}=z_{S} g$, then we can record expressions for calculating the coefficient of application the tyre-road adhesion by an automated system installed on both axes of a vehicle or on the front or rear axis only:

$$
\begin{gathered}
\varepsilon=\frac{0.849 L}{\frac{\left(t_{S} b+0.849 h\right)\left(0.566 L-0.015 a t_{i d(1)}\right)}{t_{i d(1)} b+0.566 h}+} \rightarrow \\
\rightarrow \frac{0.849 L}{\left(\frac{\left(t_{S} a-0.849 h\right)\left(0.566 L-0.01 b t_{i d(2)}\right)}{t_{i d(2)} a-0.566 h}\right.} ; \\
\varepsilon_{\text {front }}=\frac{\left(0.849 L-0.015 a t_{S}\right)\left(b t_{i d(1)}+0.566 h\right)}{\left(0.566 L-0.015 a t_{i d(1)}\right)\left(b t_{S}+0.849 h\right)} ; \\
\varepsilon_{\text {rear }}=\frac{\left(0.849 L-0.010 b t_{S}\right)\left(t_{i d(2)} a-0.566 h\right)}{\left(0.566 L-0.010 b t_{i d(2)}\right)\left(t_{S} a-0.849 h\right)} .
\end{gathered}
$$

But if the wheels rolling resistance is not considered, relations (17)-(19) will be as follows:

$$
\varepsilon=\frac{1.5}{\frac{t_{S} b+0.849 h}{t_{i d(1)} b+0.566 h}+\frac{t_{S} a-0.849 h}{t_{i d(2)} a-0.566 h}} ;
$$

$$
\begin{gathered}
\varepsilon_{\text {front }}=\frac{1.5 t_{i d(1)}}{t_{S}} \cdot \frac{t_{i d(1)} b+0.566 h}{t_{S} b+0.849 h} ; \\
\varepsilon_{\text {rear }}=\frac{1.5 t_{i d(2)}}{t_{S}} \cdot \frac{t_{i d(2)} a-0.566 h}{t_{S} a-0.849 h} .
\end{gathered}
$$

To prove the theoretical assumptions there were carried out calculations of applications the wheel traction while operation of the ABS produced by OS (Ekran) "Belarus" and the ABS designed at Kharkiv National Automobile and Highway University (KNAHU), installed on the bus MAZ 256200 on methods controlled by the UN Regulations [6].

The ABS produced by ("Ekran") [5] has an individual principle of pneumatic pressure modulators that respects peculiarities of axial driving and driving with an unstable wheel. The ABS designed at Kharkiv National Automobile and Highway University has an individual principle of control of the back axis and an axial principle of control of the front one, that, after all, ensures drivability of a vehicle. Experimental investigations were carried out under the conditions of series of braking on the dry road surface, the temperature of the environment being $30{ }^{\circ} \mathrm{C}$, and on the compacted snow cover, the temperature of the environment being $-5^{\circ} \mathrm{C}$.

During the experimental investigations there was used measuring equipment designed at the Chair of Automobiles in the name of A. B. Hredescul. The measuring equipment has 27 channels of information recording from pressure, movement, wheel rolling and acceleration gauges which were spanned on specialised spanning boards.

The results of the carried out experimental investigations of braking a bus MAZ 256200 equipped with a serial ABS ( produced by "Ekran") and a trial model of an ABS ( designed at Kharkiv National Automobile and Highway University) are presented in the tab. 1. Results of calculations by means of relations (6), (17) and (20) are presented in tab. 2. Comparison results of calculations by means of relations (6) and (20) with results of calculations by means of relation (16) we can find out the average bias of calculations. The latter is not more than $4.5 \%$ and $7.5 \%$. The correspondding biases $\Delta_{1}$ and $\Delta_{2}$ are presented in the tab. 2 . 
Results of experimental investigations of the braking process of a bus MAZ 256200 equipped with different automated systems ABS

\begin{tabular}{|c|c|c|c|c|c|c|c|c|c|c|}
\hline \multicolumn{2}{|c|}{ Marking } & $L$ & $b$ & $a$ & $h$ & $t_{S}$ & $t_{i d(1)}$ & $t_{i d(2)}$ & $t_{\text {with } A B S}$ & $t_{i d}$ \\
\hline \multirow{2}{*}{ Equipped (ABS OS “Ekran”) } & Dry road surface & \multirow{8}{*}{4,2} & \multirow{2}{*}{1,93} & \multirow{2}{*}{2,27} & \multirow{2}{*}{0,90} & 1,11 & 1,23 & 0,80 & 1,63 & 0,79 \\
\hline & Compacted snow & & & & & 3,85 & 4,10 & 2,39 & 3,57 & 1,98 \\
\hline \multirow{2}{*}{ Loaded (ABS OS “Ekran”) } & Dry road surface & & \multirow{2}{*}{1,59} & \multirow{2}{*}{2,61} & \multirow{2}{*}{0,98} & 1,86 & 1,83 & 1,14 & 1,93 & 0,91 \\
\hline & Compacted snow & & & & & 3,59 & 3,92 & 2,29 & 3,3 & 1,80 \\
\hline \multirow{2}{*}{$\begin{array}{l}\text { Equipped (ABS designed at } \\
\text { KNAHU) }\end{array}$} & Dry road surface & & \multirow{2}{*}{1,93} & \multirow{2}{*}{2,27} & \multirow{2}{*}{0,90} & 1,10 & 1,23 & 0,795 & 1,63 & 0,79 \\
\hline & Compacted snow & & & & & 3,76 & 4,10 & 2,20 & 3,57 & 1,98 \\
\hline \multirow{2}{*}{$\begin{array}{l}\text { Loaded (ABS designed at } \\
\text { KNAHU) }\end{array}$} & Dry road surface & & \multirow{2}{*}{1,59} & \multirow{2}{*}{2,61} & \multirow{2}{*}{0,98} & 1,82 & 1,83 & 1,09 & 1,93 & 0,91 \\
\hline & Compacted snow & & & & & 3,56 & 3,92 & 2,19 & 3,30 & 1,80 \\
\hline
\end{tabular}

Table 2

Results of calculation the coefficient of application the tyre-road adhesion with an automated system ABS when braking a bus MAZ 256200 in the conditions of dry road surface and compacted snow cover

\begin{tabular}{|l|l|c|c|c|c|c|}
\hline \multicolumn{2}{|c|}{ Marking } & \multicolumn{3}{c|}{ Relation number } & \multicolumn{2}{c|}{ Bias of calculations, \% } \\
\cline { 3 - 7 } & & $(17)$ & $(6)$ & $(20)$ & $\Delta_{1}$ & $\Delta_{2}$ \\
\hline \multirow{2}{*}{ Equipped (ABS OS “Ekran”) } & Dry road surface & 0,978 & 0,988 & 0,962 & 1,0 & 2,6 \\
\cline { 2 - 7 } & Compacted snow & 0,775 & 0,828 & 0,741 & 6,4 & 10,5 \\
\hline \multirow{2}{*}{ Loaded (ABS OS “Ekran”) } & Dry road surface & 0,771 & 0,798 & 0,753 & 3,4 & 5,6 \\
\cline { 2 - 8 } & Compacted snow & 0,774 & 0,786 & 0,741 & 1,5 & 5,7 \\
\hline \multirow{2}{*}{ Equipped (ABS designed at KNAHU) } & Dry road surface & 0,987 & 0,994 & 0,971 & 0,7 & 2,3 \\
\cline { 2 - 8 } & Compacted snow & 0,794 & 0,900 & 0,759 & 11,8 & 15,7 \\
\hline \multirow{2}{*}{ Loaded (ABS designed at KNAHU) } & Dry road surface & 0,787 & 0,835 & 0,769 & 5,7 & 7,9 \\
\cline { 2 - 7 } & Compacted snow & 0,781 & 0,822 & 0,748 & 5,0 & 9,0 \\
\hline
\end{tabular}

Biases of calculations $\Delta_{1}$ and $\Delta_{2}$ were defined by means of the relation

$$
\Delta_{i}=\frac{\max \left(\varepsilon_{17} ; \varepsilon_{j}\right)-\min \left(\varepsilon_{17} ; \varepsilon_{j}\right)}{\max \left(\varepsilon_{17} ; \varepsilon_{j}\right)} \cdot 100 \%,
$$

where $\varepsilon_{17}$ - value of the coefficient of application the wheel traction with operating the automated systems, that is defined by rotation $(17) ; \varepsilon_{j}-$ value if the coefficient of application the wheel traction (6), (17) and (20).

Analysis of calculation biases of the coefficient of application the wheel traction allowed finding out that calculations based on relation (6) are more accurate than the ones based on relation (20) which is does not respect the wheels rolling resistance during braking the vehicle. The biases of calculating by means of (6) is twice different from the ones based on relation on the accident.

Hence, it is possible to state that in proper to get an efficient evaluation of the accident outbreak to calculate the braking way of the vehicle by means of relation (4) we should use relations (17)-(19), which respect the rolling wheels resistance influence driving operation the automated brake proportioning system. Also relation (6) can be used, though it gives a worse result since the calculation bias in this case in up to $5 \%$.

\section{CONCLUSIONS}

1. Release of braking the wheels of a vehicle by means of the automated brake proportioning sys- 
tem results in increasing the time of braking the vehicle (itself), and, thus increasing the breaking way of a vehicle compared to the idealised process of braking the vehicle.

2 . The suggested relations (6), (20)-(22) allow evaluating the influence of the automated system of brake proportioning on the process of braking a vehicle with an average bias that does not exceed $7.5 \%$.

3. Calculations based on relation (6) have a less bias than the ones based on relations (20)-(22), since the latter do not respect the influence of the rolling wheels resistance, on the effectiveness of braking.

4. Provided that there is no criminological councils and forensic teams do not possess the information about the time of braking the vehicle, the average value of the coefficient of application the tyre-road adhesion determination can be used. This value is 0,8 applicable for an equipped and loaded vehicle regardless of the weather and climate conditions, available in the circumstances of the vehicle operation.

\section{REFERENCES}

1. Turenko A. N., Mikhalyevych N. G., Leontiev D. N. (2015) Implementation of Intelligence Functions in Electronic-pneumatic Brake Control of Vehicles. Kharkov, KhNADU Publ. 450 (in Russian).

2. Ryzhikh L. A., Klimenko V. I., Krasyuk A. N., Leont'ev D. N. (2009) Modern Anti-Lock Braking Systems and Realization of their Operational Algorithms. Izvestiya Moskovskogo Gosudarstvennogo Tekhnicheskogo Universiteta MAMI = Izvestiya MGTU “MAMI", (1), 34-37 (in Russian).

3. Renski A. (2017) Analysis of the Influence of the Drive Force Distribution Between Axles on an Automobile Stability in Its Curvilinear Motion. Conat 2016: International Congress of Automotive and Transport Engineering. Springer International Publishing, Switzerland, 55-63. https://doi.org/10.1007/978-3-319-45447-4_6.

4. Leont'ev D. N. (2010) Advanced Performance Algorithm for Controlling Anti-Lock Braking Systems (ABS). Avto- mobil'naya Promyshlennost' [Automotive Industry], (9), 25-28 (in Russian).

5. Operational Manual for Anti-Lock Braking Systems and ABS-T Brakes. Borisov, 2008. 35 (in Russian).

6. United Nations Economic Commission for Europe (2010) Regulation No 13 of the Economic Commission for Europe of the United Nations (UN/ECE) - Uniform Provisions Concerning the Approval of Vehicles of Categories M, N and O with Regard to Braking [2016/194]. Official Journal of the European Union - UN/ECE, L 42. 257.

7. Bode O. (2001) Possibilities and Limits of a Simple Tireroad Adhesion Determination - Represented at the Example of Brake Testing in Accordance with ECE-R 13. Hannover Conference on Tires, Chassis, Roads. Hannover, Germany, 69-86.

8. Hakan Koylu, Ali Cinar (2018) Development of Control Algorithm for ABS-Suspension Integration to Reduce Rotational Acceleration Oscillations of Wheel. Transactions of the Institute of Measurement and Control, 40 (3), 1018-1034. https://doi.org/10.1177/0142331216677318.

9. Jazar R. N. (2008) Tire Dynamics. Vehicle Dynamics: Theory and Aplicacion. Berlin, Springer, 95-163. https://doi.org/10. 1007/978-0-387-74244-1_3.

10. Guo K, Lu D. (2007) UniTire: Unified tire model for Vehicle Dynamic simulation. Vehicle System Dynamics, 45, 79-99. https://doi.org/10.1080/00423110701816742.

11. Villagra J., D'Andréa-Novel B., Fliess M., Mounier H. (2011) A Diagnosis-Based Approach for Tire-Road Forces and Maximum Friction Estimation. Control Engineering Practice, 19 (2), 174-184. https://doi.org/10.1016/j.conengprac. 2010.11.005.

12. Pacejka H. B. (2012) Tire and Vehicle Dynamics. Elsevier Ltd. 672. https://doi.org/10.1016/C2010-0-68548-8.

13. Braun O. M., Persson B. N., Steenwyk B., Warhadpande A. (2016) On the Dependency of Friction on Load: Theory and Experiment. EPL (Europhysics Letters), 113 (5), https://doi.org/10.1209/0295-5075/113/56002.

14. Miao Yu, Guoxiong Wu, Lingyun Kong, Yu Tang (2017) Tire-Pavement Friction Characteristics with Elastic Properties of Asphalt Pavements. Applied Sciences, 7 (11), https://doi.org/10.3390/app7111123.

15. Acosta M., Kanarachos S., Blundell M. (2017) Road Friction Virtual Sensing: A Review of Estimation Techniques with Emphasis on Low Excitation Approaches. Applied Sciences, 7 (12), https://doi.org/10.3390/app7121230.

Received: 11.01.2019

Accepted: 19.03 .2019

Published online: 30.09 .2019 